\title{
Norge må igjen øke innsatsen mot tobakk
}

$21 \%$ av den voksne befolkningen $(800000)$ røyker fremdeles i Norge. Nedgangen i andelen ungdom som røyker daglig har flatet ut de siste årene, og har nå steget fra $15 \%$ til $17 \%$ fra 2008 til 2009. I tillegg snuser $14 \%$ i aldersgruppen 16-24 år hver dag, $21 \%$ blant menn og $7 \%$ blant kvinner.

Mens innsatsen mot røyking var høy i første del av 2000-tallet, tyder de seneste røyketallene på at innsatsen de siste årene har vært utilstrekkelig. I Norge erfarer vi ikke praktisk overvåkning eller kontroll av aldersgrensen (18 år) for kjøp av tobakk. Ingeborg Rossow og medarbeidere bekrefter i sin artikkel i dette nummer av Tidsskriftet at $40-45 \%$ av røykere og snusere under 18 år i 2004 oppgir at de som oftest selv kjøper sin tobakk, et funn som er nokså uforandret sammenliknet med en liknende undersøkelse i 1999 (1).

WHOs siste tilbakemelding til Norges tobakksforebyggende arbeid påpekte at innsatsen for røykeavvenning skjer usystematisk og på en mangelfull måte, og registrerte fravær av massemediekampanjer gjennom de siste årene (2). De mente også at dagens røykelov er utilstrekkelig fordi den ikke beskytter alle mot passiv røyking, og at vi mangler en mekanisme for overvåking $\mathrm{og}$ håndheving av eksisterende regelverk, som for eksempel forbudet mot salg av tobakksvarer til mindreårige. Videre påpekes utilstrekkelige ressurser til tobakksforebygging, og at kunnskapen i helsetjenesten om viktigheten av røykeavvenning og hvordan det kan gjøres på en kunnskapsbasert måte er for dårlig. Statssekretær Roger Ingebrigtsen uttaler dermed: «Norge skal igjen bli ledende i det internasjonale tobakksarbeidet. Røyking er fortsatt den viktigste årsaken til sykdom og død som kan forebygges» og varsler en ny nasjonal tobakksstrategi for perioden 2011-15.

Som en reaksjon på den globale tobakksepidemien, etablerte WHO sitt Framework Convention on Tobacco Control (FCTC) som representerer et paradigmeskifte i reguleringen av avhengighetsskapende stoffer. Norge var det første landet som ratifiserte denne konvensjonen, som ble virksom i 2005 og nå har 165 medlemsland, dermed en av de mest omfavnede konvensjoner i FNs historie. Jamført med anbefalinger for utviklingen, implementeringen og håndhevingen av en røykfri lovgivning i artikkel 8 var Norge tidlig ute med loven om røykfrie utesteder i 2004 (3). Loven har vært en formidabel suksess. Videre presiserer FCTC at helseadvarsler på tobakkspakkene må dekke minst $30 \%$ og burde dekke minst $50 \%$ av røykpakkens for- og bakside. FCTC foreslår å øke størrelsen på helseadvarslene, at hver sigarett skal ha et piktogram med helseadvarsel, at alle tobakkspakker skal ha samme farge (brun), at logoer eller designelementer blir forbudt og at salgsnavnet skal stå med standard skrift, størrelse og plassering på alle produkter.

Helseadvarsler på tobakkspakkene er oppfattet som det mest kostnadseffektive kommunikasjonsmedium mellom helsemyndighetene og røykerne som er tilgjengelig - bestemt av myndighetene og betalt for av tobakksselskapene. Det kan likevel stilles spørsmålstegn ved om denne tilnæringsmåten er spesielt effektiv overfor voksne norske røykere i dag, som mer enn noen gang preges av lavere utdanningsnivå og sosial klasse og høy nikotinavhengighet. Denne gruppen endrer ikke nødvendigvis livsstil pga. allmenn helseinformasjon, skriftlig eller gjennom massemediene, men påvirkes lettere av personlig kommunikasjon og rådgivning.
Derfor kan sannsynligvis engasjerte fastleger best hjelpe dagens røykere til røykestopp, siden $75 \%$ av røykerne besøker sin lege i en 3-5 årsperiode. Dose-respons-forholdet ved individuell røykeavvenning er veletablert; jo mer du gjør, jo bedre virker det. Individuell røykeavvenning i regi av lege vil i gjennomsnitt føre til 50\% flere røykfrie sammenliknet med hvis legen ikke engasjerer seg i problematikken. Vi snakker om en formidabel effekt på folkehelsen. «Minimal intervensjon» er minstekravet i dag, bestående av følgende 3 elementer: 1) Røyker du? 2) Hva tenker du om det at du røyker? 3) Jeg vil anbefale deg å slutte! Under punkt 2 er det nettopp viktig med det åpne spørsmålet: Hva tenker du? Med denne type spørsmål vil man lett få frem pasientens ambivalens, nemlig både hvorfor man vil slutte og hvorfor man vil fortsette. Med et åpent innledende spørsmål blir samtalen mer ærlig og ikke minst bedre og morsommere for legen, noe som er viktig for en som bør ta disse samtalene flere ganger om dagen. Et lukket spørsmål, f.eks.: «Det er vel på tide å slutte nå, synes du ikke det?» avslører lett legens moralisme rundt røyking og resulterer ofte $\mathrm{i}$ at pasienten ikke gidder å snakke med legen om problemstillingen. Samtalen blir deretter og intervensjonen uvirksom. I en norsk undersøkelse svarer norske fastleger at den største hindringen for å ta opp røyking var at det tok lang tid (4). «Tidsklemma» er helsevesenets største utfordring, og selvsagt også når det gjelder livsstilsintervensjon. Dette er kanskje ikke så overraskende i et system hvor personlig inntekt i stor grad avhenger av kvantitet og ikke av kvalitet.

Leger kjenner skadevirkningene av tobakk bedre enn de fleste og bør derfor samlet støtte de forslag FCTC kommer med for å begrense tobakksepidemien. Samtidig bør leger bidra til effektive røykeavvenningstiltak både lokalt og nasjonalt og tilegne seg gode samtaleteknikker ved livsstilsendring. Røykeavvenning er fremdeles den mest kostnadseffektive intervensjon i både primær- og sekundærforbyggende hensikt (5). Legene som gruppe må fortsatt øke innsatsen mot røyking og snusing. Samtidig må myndighetene bruke ressurser på å skjerpe og håndheve lovgivningen som er meget godt begrunnet. Vi ser frem til en ny giv i det tobakksforebyggende arbeidet.

\section{Frode Gallefoss \\ frode.gallefoss@sshf.no}

Frode Gallefoss, f. 1956, er seksjonsoverlege dr.med. ved Sørlandet Sykehus, Kristiansand og professor ved Universitetet i Bergen.

Oppgitte interessekonflikter: Ingen

Litteratur

1. Rossow I, Pedersen W, Lund KE. Kjøp av tobakk blant mindreårige. Tidsskr Nor Legeforen 2010: 130: 1337-9.

2. Helse- og omsorgsdepartementet. www.regjeringen.no/nb/dep/hod/ pressesenter/pressemeldinger/2010/Fornyet-innsats-mot-tobakk.html?id= 603520 (16.6.2010)

3. World Health Organisation. Guidelines for implementation of the WHO Framework Convention on Tobacco Control. 2009. www.who.int/fctc/guidelines/en/ index.html (10.6.2010)

4. Gallefoss F, Drangsholt K, Røykeintervensjon og hindringer for dette blant fastleger i Vest-Agder. Tidsskr Nor Lægeforen 2002; 122: 2608-11.

5. Parrott S, Godfrey C. Economics of smoking cessation. BMJ 2004; 328: 947-9. 